\title{
UN CANTO DE ACANTO. LA POESÍA PERUANA DEL NUEVO MILENIO
}

\author{
Catalina Quesada Gómez \\ Universidad de Sevilla
}

\begin{abstract}
This article approaches Eucaristia (2004) by the Peruvian poet Róger Santiváñez (Piura, 1956). This work is inscribed in a tendency that could be called «baroquicizing», whose main interest lies in rhythmic and phonic aspects. At the same time, we study the eucharistic project in the context of Santiváñez's previous poetical production and his connections to the Kloaka Movement (1982-1984).
\end{abstract}

su espiritu es la hostia de mi amorosa misa,
y alzo al son de una dulce lira crepuscular
Rubén Darío, Prosas profanas

La trayectoria poética de Róger Santiváñez (Piura, 1956) lo encumbra en el parnaso de las letras peruanas, mirando allí de frente a uno de los más grandes de la poesía hispánica, al César de los poetas en lengua española. Desde Antes de la muerte (1979), engrosan los anaqueles de su producción Homenaje para iniciados (1984), El chico que se declaraba con la mirada (1988), Symbol (1991), Cor Cordium (1995) y Santa Märía (2002); al igual que la narrativa poética de Santísima Trinidad (1998), Historia francorum (2000) o El corazón zanahoria (2002). La reciente publicación de Eucaristía (Buenos Aires, Tsé-Tsé, 2004) contribuye a su consolidación como poeta barroquizante, absolutamente preocupado por la materia prima de todo escritor: el lenguaje. Su vinculación con la tradición peruana, en especial en obras como Symbol, responde a las fervientes lecturas del Vallejo de Trilce o del Martín Adán de Travesía de extramares y, como él mismo reconoce, asume «la perspectiva desde la cual escribieron Vallejo o Adán [...], no su lenguaje, obviamente. Y ésa es la de la libertad y la del arduo trabajo del lenguaje»!

Santiváñez ha hecho suya la tríada de André Breton, Vida-Obra-Actitud (Ildefonso), y se enfrentó a la vida con la adarga de la poesía y el compromiso férreo de luchar contra un sistema que lo relegó, cual poeta maldito, a la más absoluta de las marginalidades. En los 70 y principios de los 80 participó en los grupos Auki (1974-1976), La Sagrada Familia (1977-1979) y Hora Zero $2^{a}$ Fase (1980-1981), antes de co-fundar el estado de revuelta poética Movimiento Kloaka, en septiembre de 1982, del cual formaron parte, entre otros, Guillermo Gutiérrez, Mariela Dreyfus, el narrador Jorge Edián Novoa y, más tarde, Domingo de Ramos, José Velarde, Julio Heredia, Mary Soto, el pintor Carlos Enrique

\footnotetext{
${ }^{1}$ M. Ildefonso, «El fuego de la poesía. Entrevista al poeta Róger Santiváñez», Ciberayllu (20 de septiembre de 2004). <http://www.andes.missouri.edu/andes/Cronicas/MI_Rsantivanez.html>
} 
Polanco y los aliados principales José Antonio Mazzotti y Dalmacia Ruiz-Rosas. En Piura, al Norte del Perú, se constituyó Nor-Kloaka, con Lelis Rebolledo, el músico Estanislao Quesada y el pintor César Badajoz; en París, ya en 1986, José Velarde publicaría dos números de la revista Kloaka internacional ${ }^{2}$.

\section{HACIA EL PROYECTO EUCARÍSTICO}

Eucaristía, al igual que el resto su obra, versa sobre los ejes de la Historia, el Eros y la Poesía misma. Pese a ser éstos sus demonios personales, ha ido variando, con el paso del tiempo y los cambios en su entorno, la importancia concedida a cada uno de esos motivos: el compromiso social y político patente en su obra más temprana y manifiesta en algunos de los textos programáticos de $K l o a k a^{3}$ ha ido cediendo terreno, primero a la preocupación erótica, intensa en Homenaje para iniciados, como en casi todos sus poemarios, y después al ansia por el lenguaje total, pleno, con una experimentación radical en cada verso, en cada palabra, cual amante que se detiene y paladea cada pliegue del cuerpo (poético) amado y no necesita del mundo externo para existir. Ha sido su itinerario poético, hasta el momento, un viaje hacia la semilla, un periplo desde el exterior hacia el interior de sí y del lenguaje.

\footnotetext{
${ }^{2}$ Para la historia de Kloaka, véanse los trabajos de J. Zevallos Aguilar, Movimiento Kloaka (1982-1984): Cultura juvenil urbana de la postmodernidad periférica, Lima, Editorial Ojo de Agua, 2002; o de J. A. Mazzotti, Poéticas del flujo. Migración y violencia verbales en el Perú de los 80, Lima, Fondo Editorial del Congreso del Perú, 2002, en concreto, el capítulo $4^{\circ}$, «El flujo subterráneo», pp. 131-172, donde, además de analizar el fenómeno de la Kloaka, estudia la obra de dos de sus integrantes, Domingo de Ramos y Róger Santiváñez. Resumiendo, diremos que Kloaka fue un movimiento de neovanguardia de vida efímera (1982-1984), una corriente artística contracultural, no sólo reducida al ámbito literario, sino extensiva también a la música, la pintura, la escultura, la fotografía o el audiovisual. José Antonio Mazzotti los ha caracterizado apelando, en primer lugar, al hipercultismo lúdico, pero también a la polifonía dentro de un mismo texto y a la existencia de una poesía del lenguaje, con el «quiebre de la lógica denotativa para explotar formas de expresión cercanas al discurso esquizoide y a una suerte de neovanguardismo cuyos nexos pueden ser rastreados en el ya lejano pero aún influyente Trilce de Vallejo» (Mazzotti 2002b: 133-134). La fugacidad del movimiento no impedirá que los integrantes desarrollen, con posterioridad e individualmente, las propuestas estéticas y políticas ensayadas en el laboratorio grupal (Zevallos Aguilar: 31-33); en palabras de César Ángeles, «los poetas entran en un proceso de archipielagización creciente. Cada vez es más evidente la poca voluntad e interés por hacer las cosas grupalmente», "Aproximación a la poesía peruana de los 80. Punto de partida: la poesía de Róger Santiváñez», Ciberayllu (12 de agosto de 2001). $<\mathrm{http} / /$ www.andes.missouri.edu/andes/Especiales/CALRoger/CAL_Roger1.html>. A Róger Santiváñez se lo consideró caudillo de Kloaka.

${ }^{3}$ En «Primer texto (manifiesto)», firmado por Róger Santiváñez y leído en el recital «La Poesía Joven», que organizó el Movimiento Kloaka el 21 de abril de 1983, constatamos su vocación de compromiso: «El Movimiento Kloaka desde su fundación ha reivindicado la vida, la intensa realización de la vida, es decir, la liberación como la forma más perfecta de oponerse al dolor social que nos golpea todos los días y a cada momento, y al hecho incontrastable que gobierna la condición humana: la finitud, la muerte.

»Se trata entonces, de que el poeta, el artista en Latinoamérica, tiene en primer lugar la tarea de crear una obra que sea su primera y más contundente propuesta. Y en segundo lugar, dadas las condiciones históricas que padecen nuestras sociedades, le corresponde al artista el rol de crítico, sacerdote, agitador radical, maestro de escuela; es decir, movilizador de la conciencia de la mayor cantidad de personas, ya que la experiencia poética no es patrimonio ni exclusividad de nadie; sino que existe como fuerza potencial en todo ser humano. [...]

»Porque hemos venido a encontrar la plenitud. A organizar una rebelión con lucidez, una rebelión que no vacile ante el riesgo, porque aquí no hay nada qué [sic] perder y sí mucho que ganar: llegar al corazón de la gente, proponer que la Revolución es posible porque bulle en nuestras angustias y nuestras visiones. Porque no vamos a morir, sin antes construir el mensaje que pueda transformarnos y así ofrecer nuestra propia vida como prueba de nuestro más hermoso deseo: vencer al tiempo y liquidar el dolor que a todos nos alcanza, para que se convierta en una música, un color, una palabra; que sea, de una vez y para siempre, como escribió Luis Hernández: LA SONADA COHERENCIA» (Zevallos Aguilar: 82-83); el subrayado y las mayúsculas son del autor .
} 
Camino inverso al de Vallejo el suyo («es que yo no soy vallejo yo soy santiváñez el que no / comprendió el feo saludo del lumpen cuando nadie lo detesta», dirá el sujeto, poético o no, de «Liberación», en Symbol).

Los inicios comprometidos del poeta han sido destacados por Paolo de Lima bajo el epígrafe «Róger Santiváñez: de la solidaridad a la incomprensión del lumpen» ${ }^{4}$; en ese trabajo analiza el poema «Reflexiones junto a la tumba del loco Vicharra», publicado en enero de 1983, que es entendido por el crítico como una toma de posición por parte de Santiváñez ante la violencia creciente a principios de los 80 en el Perú. Pero Paolo de Lima se muestra consciente de que la obra del piurano deriva por otros derroteros a partir tan sólo del año siguiente, cuando se publica Homenaje para iniciados; de ahí su comentario a raíz de unos versos de Symbol: «el autor ha pasado de la clara denuncia y rebeldía ante el estado de cosas, y de la representatividad de los actores sociales marginados, que lo caracterizaban en cierta medida durante los años del activismo de Kloaka, a la expresión, tanto en su vida como en su obra, de la automarginación y el malditismo. [...] El resultado: el testimonio de una época a través de una poesía mucho más profunda y personal, altamente elaborada y compleja, y anclada en la efervescente realidad política y social que al autor le tocó vivir» (De Lima: 287). Dicha tendencia se intensificará en Eucaristía, que constituye, por el momento, la culminación de este proceso audaz.

Por eso es necesario constatar que Eucaristía no surge ex nihilo; hay maneras en su poesía anterior que apuntaban a este autismo del verbo cifrado, a la exuberancia barroca, a esta fiesta eucarística del lenguaje. Mauricio Medo Ferrero ha percibido la ausencia de ruptura entre este poemario y los anteriores, entre los cuales se advierte, en efecto, una firme gradación ${ }^{5}$. Ya José Antonio Mazzotti anunciaba, a propósito de obras anteriores, lo que ahora encontramos, al subrayar que en el poeta «se da no sólo una barroquización superlativa de todos los niveles de expresión poética, desde los fonéticos hasta los tropológicos, sino el cuestionamiento de la misma escritura poética como tal y del sujeto poético unilineal, mucho más allá de los límites del montaje eliotiano y de las estructuras dramáticas ya ensayadas en la poesía peruana desde los años 60» (2002b: 152). Su lenguaje florido, críptico, selecto, cercano al cultismo de la mejor tradición gongorina ${ }^{6}$, también veteado de americanismos, aleja este poemario de la poesía coloquial o conversacional que

\footnotetext{
${ }^{4}$ P. de Lima, "Violencia y "otredad" en el Perú de los años 80: de la globalización a la "Kloaka"», Revista Crítica Literaria Latinoamericana XXIX, 58 (Lima-Hanover, 2003), pp. 275-301; el apartado en cuestión se encuentra en las pp. 283-289.

${ }^{5}$ «El resplandor de su Eucaristía corona un proceso literario [...] iniciado con su emblemático Symbol», M. Medo Ferrero, «Repensando la poesía peruana: una Babel en el continente latinoamericano», www.letras.s5.com. $<$ http://www.letras.s5.com/lp140105.htm>

${ }^{6}$ La presencia de Góngora en el poemario la cerciora la cita inicial, perteneciente a la segunda de las Soledades: «la que en el torcido / luciente nácar te sirvió no poca / risueña parte de la dulce fuente». De cualquier modo, e hermetismo de Eucaristía, la presencia de hipérbatos y anástrofes de factura neobarroca, así como la proliferación de neologismos, cultismos y latinismos, entre otros recursos, son de por sí suficientes para invocar el espíritu del poeta cordobés. No olvidemos la formación literaria recibida por Santiváñez: luego de estudiar con los jesuitas en Piura, y de cursar un año de Periodismo en la Universidad de su ciudad natal, se marchó en 1975 a Lima para graduarse en Literatura en la Universidad de San Marcos. En la actualidad, se está doctorando en Literatura en Temple University, Philadelphia.
} 
practicara en sus inicios y a la que volviera, sólo en parte, en Santa María ${ }^{7}$. El hermetismo lingüístico del libro que comentamos tiene precedentes, tanto en Homenaje para iniciados, cuyo título, de resonancias cuasi-modernistas, habla por sí solo del elitismo pretendido, como en Symbol, donde se parte del argot del lumpen nocturno limeño para construir una obra que, por momentos, deja al lector «excluido del circuito de la comunicación» ${ }^{8}$.

En Eucaristía asistimos a la explosión del lenguaje, de una lengua, la española, que salta en pedazos y se fragmenta para provocar nuevas uniones insospechadas, en las que tendrán cabida otros idiomas (latín, inglés, italiano, francés, quechua); de una lengua que resurge prístina y goza de sí misma al entregarse en el ofertorio de la recitación poética, en

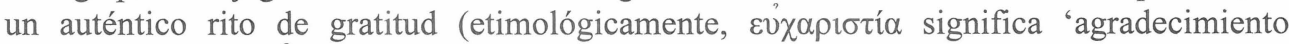
acción de gracias' $)^{9}$. Las nueve partes en que se divide el libro («Sajonia», «Cántico», «Eucaristía», «Adonáis», «Lúdica», «Bordado de encaje», «Lied», «Gema» y «Egus») presentan distintos tonos y extensión, desde los trece poemas que integran «Eucaristía»a las tres líneas de «Egus»; desde el canturreo sonoro del arte menor de «Cántico», con versos que bien podría albergar el canto VI de Altazor («vuela perla-aire // marítima vacíame», p. 19 , vv. $3-4)^{10}$, hasta el versolibrismo seudonarrativo y complejo de «Bordado de encaje».

\section{EL NEOBARROCO}

Sabido es que hablar del neobarroco en la literatura hispanoamericana exige hacerlo atendiendo a criterios geográficos, dado que cada país ha desarrollado una teoría y una praxis específicas de lo barroco ${ }^{11}$. Quizá uno de los más acreditados sea el cubano, con las

\footnotetext{
${ }^{7}$ Es el poeta quien incide en que su lenguaje «fue tributario del Conversacionalismo» en Antes de la muerte y que escribió Santa María «en un regreso temporal a mi ciudad natal de Piura, viaje que también significó una vuelta (una estación) en el Conversacionalismo que me vio nacer» (Ildefonso).

${ }^{8}$ E. Urdanivia, «Symbol. El cuaderno músico de Róger Santiváñez», Sietevientos, 5 (Piura, 1993), pp. 17-38; la cita corresponde a la p. 23. También Mazzotti ha referido esta característica de la poesía de Santiváñez, a propósito de Symbol y de Cor Cordium: «en estos dos libros, sin embargo, la actitud de enfrentamiento al lector, el sentido provocador de sus imágenes y el dislocamiento de un sujeto poético que se disgrega entre los paraísos artificiales y la persecución sexual más desenfrenada nos presentan a un poeta novedoso y un lenguaje que se ofrece como contrapunto y superación de la retórica meramente narrativa y coloquialista ya consagrada en la poesía peruana» (2002b: 171).

${ }^{9}$ El DRAE, en su tercera acepción para el adjetivo eucarístico, nos ofrece la siguiente definición: ‘dícese de las obras en prosa o verso cuyo fin es dar gracias'.

${ }^{10}$ Huidobro, como Góngora y como la pléyade de poetas peruanos (César Vallejo, César Moro, Martín Adán, Oquendo de Amat, Javier Heraud o Rodolfo Hinostroza), asiste al poeta en el oficio eucarístico. El eco altazoriano es indudable por la primacía del sonido sobre todo lo demás, mas acude también Huidobro, invocado por el texto, en varias ocasiones: «Un mar celeste como el cielo que en Colán // fundó contigo silueta fijada / horizon carré // línea frágil entre tú el cielo \& el mar» (p. 23, vv. 1-3). Debido a que el poeta inserta con frecuencia el signo / en medio de sus versos, nos tomamos a partir de ahora la licencia de marcar siempre con doble / el final del verso, evitando así confusiones.

${ }^{11}$ El poeta argentino Néstor Perlongher (1949-1993) acuñó a mediados de los 80 el término neobarroso para aludir a la poesía neobarroca que se realizaba en la zona rioplatense. Pueden consultarse al respecto N. Perlongher, «Neobarroco y neobarroso», en AA. VV., Medusario. Muestra de poesía latinoamericana, México, Fondo de Cultura Económica, 1996, pp. 19-30; o E. Milán, «Neobarrosos», Zunái. Revista de Poesía \& Debates. $<$ http://www.revistazunai.com.br/ensaios/eduardo_milan_neobarrosos.htm>. Más genéricos son los trabajos de O. Calabrese, A idade neobarroca, São Paulo, Martins Fontes, 1987; I. Chiampi, Barroco y modernidad, México,
} 
figuras de Lezama Lima, Carpentier, Cabrera Infante y Severo Sarduy a la cabeza; los trabajos teóricos de casi todos ellos, caracterizados por su extrema rigurosidad, supusieron un espaldarazo para la consagración de dicha tendencia. Sin embargo, el término neobarroco se ha empleado con posterioridad para referirse a realidades literarias muy diversas; como señala Gonzalo Celorio, el modelo de Sarduy ${ }^{12}$, basado en la parodia y el artificio, «propicia la extensión del término neobarroco a obras muy diversas, al grado que no sería una exageración tomar la barroquicidad [...] como una de las señas de identidad de la narrativa hispanoamericana contemporánea» ${ }^{13}$. En lo concerniente a la poesía, el crítico y poeta Roberto Echavarren, ha realizado una meritoria tentativa de síntesis para ofrecer una definición aproximada de lo que constituye la esencia neobarroca:

La nueva poesía, además, a través de José Lezama Lima, se asoma a la poesía barroca escrita en español. No apuesta, como en el caso de las vanguardias, a un método único o coherente de experimentación. Ni se reduce a los referentes macropolíticos de la toma del poder o del combate contra la agresión imperialista. Es impura: ora coloquial, ora opaca, ora metapoética. Trabaja tanto la sintaxis como el sustrato fónico, las nociones como los localismos. Y pasa del humor al gozo. La poesía neobarroca es una reacción tanto contra la vanguardia como contra el coloquialismo más o menos comprometido. a) Comparte con la vanguardia una tendencia a la experimentación con el lenguaje, pero evita el didactismo ocasional de ésta, así como su preocupación estrecha con la imagen como icono, que la lleva a remplazar la conexión gramatical con la anáfora y la enumeración caótica. Si la vanguardia es una poesía de la imagen y de la metáfora, la poesía neobarroca promueve la conexión gramatical a través de una sintaxis a veces complicada. [...] b) Aunque pueda resultar en ocasiones directa y anecdótica, la poesía neobarroca rechaza la noción, defendida expresa o implícitamente por los coloquialistas, de que hay una «vía media» de la comunicación poética. Los coloquialistas operan según un modelo preconcebido de lo que puede ser dicho, y cómo, para hacerse entender para adoctrinar a cierto público. Los poetas neobarrocos, al contrario, pasan de un nivel de referencia a otro, sin limitarse a una estrategia específica, o a cierto vocabulario, o a una distancia irónica fija. Puede decirse que no tienen estilo, ya que más bien se deslizan de un estilo a otro sin volverse los prisioneros de una posición o procedimiento ${ }^{14}$.

En el ámbito peruano, es preciso mencionar la tesis doctoral de Rafael de la Fuente Benavides (Martín Adán), De lo barroco en el Perú, pero también remitir a su actividad poética, en especial a Travesía de extramares, de índole indudablemente barroca o neobarroca, con abundantes arcaísmos y un hermetismo de cuño cuasi-conceptista. A pesar de que la crítica ha cuestionado la concepción de lo barroco defendida por Martín Adán en su tesis, más cercana, tal vez a la de lo romántico, De lo barroco en el Perú nos ofrece

Fondo de Cultura Económica, 2000; así como R. Romero, «Barroco y Neobarroco. Naturaleza, apoteosis, dificultad, oscuridad», Babab, 22 (noviembre 2003). <http://www.babab.com/no22/neobarroco.php>

${ }^{12}$ Los principales trabajos de Sarduy sobre el barroco (Escrito sobre un cuerpo, Barroco, La simulación, Nueva inestabilidad) han sido recogidos en Ensayos generales sobre el barroco, México-Buenos Aires, Fondo de Cultura Económica, 1987. Es fundamental su artículo «El barroco y el neobarroco», en C. Fernández Moreno (coord.), América Latina en su literatura, México, Siglo XXI, 1972, pp. 167-184.

13 G. Celorio, «Aproximación a la literatura neobarroca», Letras de Chile. $<$ http://www.letrasdechile.cl/modules.php?name=News\&file=article\&sid=582>

${ }^{14}$ R. Echavarren, «Prólogo», en AA. VV., Medusario. Muestra de poesía latinoamericana, México, Fondo de Cultura Económica, 1996, pp. 11-17; la cita corresponde a las pp. 13-14. 
puntualizaciones que no debemos desechar, como la de la constatación de la existencia de un barroquismo intrínseco a la literatura peruana: «El culteranismo, afirma L. A. Sánchez, es un modo de expresión anterior al gongorismo en la literatura del Perú. La ya formal actitud para el amaneramiento, para la circunelocuencia, para aquello por lo cual el sentido se supedita al modo, y éste lo confunde y configura, viene en el Perú, y por lo tanto en la América española, apenas diferenciado si no es por la geografía peninsular» ${ }^{15}$. Pablo Granados, en «De lo neobarroco en el Perú», cita, entre los contemporáneos, a poetas como Julio Ortega, Vladimir Herrera, Magdalena Chocano, José Antonio Mazzotti, Gabriel Espinoza Suárez o Frido Martín; podemos añadir ahora en la nómina del neobarroco peruano al poeta Santiváñez, en especial con la que, por el momento, es su última obra. Para Granados es la década del 80 la del resurgir del barroquismo peruano, cuando «las fuerzas barrocas adquieren nuevos bríos en el Perú y, justamente, a partir de la poesía conceptista / coloquial del autor de Diario de poeta. Claro está, en un neobarroco que, asimismo, ha ido incorporando otros gustos de moda y, es lo más remarcable, otros gestos de estilo hasta hacerse casi irreconocible canónicamente» ${ }^{16}$.

Róger Santiváñez se alinea con el neobarroco hispanoamericano, pero también con los poetas del 27 español, en la recuperación del cordobés. Esa peculiar síntesis de los españoles entre tradición e innovación vanguardista, asimismo presente en Eucaristía -en un momento en que, según Siebenmann, habríamos alcanzado en la poesía hispanoamericana la paliación de la tradición de la ruptura de que hablara Octavio Paz-, estrecha los vínculos entre uno y los otros. Además, la presencia, ora implícita, ora explícita del 27 en el poemario es un hecho constatable: el sentimiento de exclusión y marginalidad, tan cernudiano, y el enfrentamiento de dos mundos antagónicos presentes en Poeta en Nueva York impregnan los poemas de «Sajonia» («en Sajonia aún no existo», p. 11, v. 17; «Mi canción es triste por el viento de esta hora // en que escucho la porfía de Míriam // por irse a los United», p. 13, vv.1-3); o el tributo a Jorge Guillén en la sección «Cántico», muy distinta del resto de la obra, con un acercamiento, ma non troppo, a la pureza poética, a «aquella desnuda // perfección» (p. 16, vv. 5-6):

$$
\begin{aligned}
& \text { En ti está el ritmo } \\
& \text { bajo la cantidad azul } \\
& \text { dándole amor a los } \\
& \text { cuerpos soñados } \\
& \text { Eso es lo frágil. } \\
& \text { He allí la pureza } \\
& \text { etérea enviada } \\
& \text { de tus labios } \\
& \text { bañados en dulzor } \\
& \text { («Cántico», 4, p. 18) }{ }^{17}
\end{aligned}
$$

\footnotetext{
${ }^{15}$ M. Adán, De lo barroco en el Perú, en Obras en prosa, Lima, Ediciones Edubanco, 1982, p. 371. Véase con atención el capítulo II, «Peralta y los culteranos» (pp. 371-400), donde el autor estudia el influjo de Góngora en las letras peruanas, un terreno ya abonado para recibir al cordobés. Agradecemos a la profesora Gema Areta su aportación bibliográfica en este ámbito.

${ }^{16}$ P. Granados, «De lo neobarroco en el Perú», www.letras.s5.com. <http://www.letras.s5.com/pg150305.htm>

${ }^{17}$ Santiváñez se muestra escéptico a propósito de la pureza: «la imagen de la pureza como una utopía inalcanzable o una salvación que podría relacionarse a los paraísos o cielos de las religiones. Pero en realidad es la misma
} 
Quizá hayamos de tener en mente la cita que abre Eucaristía, no ya sólo como declaración de intenciones acerca de la oscuridad (lingüística), del hermetismo y plurivalencia del lenguaje que hallaremos, sino también como orientación temática para la lectura de, al menos, la primera sección del poemario, «Sajonia». Desde el exordio de la obra que Santiváñez invoca en el epígrafe, Góngora anuncia que pasos de un peregrino son errante; Mauricio Molho, que ha escudriñado los posibles sentidos de la utilización del término peregrino en las Soledades, concluye que «el protagonista es peregrino porque es extranjero en la región a la que la Fortuna le condujo: Góngora le califica a veces de extranjero o de forastero. Venido de lejos, el peregrino es el exiliado entre los que le rodean: su condición de ser único, diferente de los demás, le obliga a la soledad. Pero peregrino evoca también en la lengua clásica, la cualidad de lo que es raro, extraño, fuera de lo común, y, por eso mismo, "precioso": designa siempre lo no-trivial, lo superlativo, lo inaudito» ${ }^{18}$. La identificación entre este peregrino y un poeta heredero del malditismo simbolista, incluso modernista, es más que viable ${ }^{19}$. El sujeto lírico de «Sajonia», exceptuando tal vez el tercero de los poemas, ejerce la labor poética: «Soy el carmen que canta en el canto del chilalo» (p. 11, v. 18); «Mi canción es triste por el viento de esta hora» (p. 13, v. 1). De ahí que el estremecimiento por la exclusión, por ese ostracismo de albatros a que parece relegado («Voy por los caminos seguramente fútbol // desprovisto de linternas, de rigurosos esfínteres // cerrados», p. 13, vv. 7-9), sea también el del escritor, el del poeta: «Aquí es el tono de la franca indiferencia // aquí la pista en que Juan murió atropellado» (p. 14, vv. 2-3); versos estos últimos que, según el propio Santiváñez, sugieren «lo esencial del poeta que enfrentado al sistema, muere trágicamente» ${ }^{20}$.

La preponderancia del elemento acuoso en «Cántico», la segunda sección, remite nuevamente a la cita gongorina (la que en el torcido / luciente nácar te sirvió no poca / risueña parte de la dulce fuente), un agua de estirpe erótico-amorosa («Soy surtidor purísimo / // brota a borbotones // el agua de mi doncel», p. 15, vv. 2-4), pero también, y simultáneamente, ofrenda castalia de silenciada Éfire:

Silencio fortuito.

Sorbo de la fuente

poesía. Un estado de gracia sería la poesía. [...] Hablamos de una pureza que no existe pero que es. Como esa utopía, que sólo mora en nuestros corazones angustiados. Y que transformamos en belleza» (Ildefonso). En el octavo de los poemas de «Eucaristía», el sujeto lírico exclama «Creación pura aunque ni la poesía sea // Pura pero qué es la pureza qué es dime // Todo esto» (p. 28, vv. 3-6).

${ }^{18}$ M. Molho, Semántica y poética (Góngora, Quevedo), Barcelona, Crítica, 1977, p. 55.

${ }^{19}$ José Antonio Mazzotti se referirá al malditismo como «la veta más característica de este autor» (2002b: 156), no sólo con el malditismo anarcoide de sus años de experimentación con la Kloaka, sino incluso después, con uno de cuño estético, que lo vincula con los poetas malditos del XIX francés: «El malditismo, que no es nuevo en la poesía peruana y mucho menos en la occidental, surgía entonces [con Homenaje para iniciados] de manera clara desde una postura pretendidamente elitista» (Mazzotti 2002b: 157). El título de su libro de 1991, Symbol, así como la dedicatoria del mismo («éste es mi cuaderno músico»), siguen entroncando a «san tiváñez» con el movimiento francés.

${ }^{20}$ Partiendo que la disemia que entraña el verso (ese Juan aludiría tanto a Juan Vega como a Juan Ojeda, ambos poetas con un cierto halo de malditismo, muertos tempranamente y de forma trágica), el sentido final supera lo anecdótico para alcanzar ese valor genérico a que alude Santiváñez de enfrentamiento del poeta con el mundo. Véase la entrevista de Ildefonso, de donde tomamos la cita. 
de mi soledad

$\begin{aligned} & \text { gotas fugaces en la dorada } \\ & \text { piel de aquella desnuda } \\ & \text { perfección }\end{aligned}$
(«Cántico», 2, p. 16, vv. 1-6)
Suavísima antiquísima
poesía son tus ojos
mis mejores augurios
dátiles jugosos o
lágrimas secadas
para esta música
combinada perfecta-
mente a tu oscuridad
sentimental.
(«Cántico», 3, p. 17)

Y del agua de «Cántico» a la luz poético-eucarística de la tercera sección, la más barroca, acaso, del poemario. En «Eucaristía» las referencias mitológicas, paganas, se entremezclan con las religiosas («Azur bóveda ingrávida perfección // Que dó naturaleza muerta stella // Maris que Paris no pudo alcanzar», p. 21, vv. 10-12), en un lenguaje tendente a prescindir de nexos que ensombrezcan la esencia plurisignificativa de las palabras y la superposición de imágenes: «Pétalo sé mi canción exquisita // Squizofrénica forado escape divino // Hacer poesía lingua franca vulva // Volada pasionaria honoris causa» (p. 22, vv. 5-8). Una lengua apátrida y exuberante que, negadora de toda posibilidad esticomítica, fluye y se derrama de verso en verso en un eterno encabalgarse. Puestos a no aceptar lindes ni fronteras, hasta los conceptos desbordan la unicidad léxica y prolongan su eco mediante poliptotos que los desarrollan e intensifican: «Créame pura en la pureza purificada // En la purifícación de tu rebeldía» (p. 23, vv. 7-8). Y las palabras violentan el orden establecido para instaurar el caos anárquico de presentidos hipérbatos que terminan no siéndolo, de agresivas anástrofes («spuma // Que volví a refrescar santuario in», p. 22, v. 15; «oscurece húmeda músician de tu boca filigrana vuelta re», p. 39, v. 13) e imponer una nueva sintaxis de ardua legibilidad regida por parámetros distintos a los de la lengua que los no iniciados manejamos. El resultado, sorprendente, descoloca al lector, provocándole esa inquietud vertiginosa de quien ha de olvidar lo que sabe para tornarse permeable ante una nueva lengua (lingua franca) que le permita deleitarse con esas «flores que brillaran en el abismo» ${ }^{21}$ que son los poemas de Eucaristía.

\section{Y EL SONIDO Y EL SONIDO}

La búsqueda de un nuevo lenguaje poético, armónico, desemboca en la eufonía que arrastra al lector hacia una anhelada belleza fónica. De ahí los momentos extáticos, en que, olvidados de toda significación, nos dejamos llevar por el torrente de aliteraciones,

${ }^{21}$ R. Zurita, «La letra en que nació la pena: muestra de poesía peruana 1970-2004», www.letras.s5.com. $<$ http://www.letras.s5.com/lp150105.htm> 
paronomasias, geminaciones, rimas dobles o internas, versos leoninos, rimas encadenadas o al mezzo, como sucede en el primero de los poemas de «Adonáis»:

Gema o jerma ábrete corral corrido
Warike lampo cachina huida
Lámpara ampara Mara
Mármara murmura radio futura
Hiena herida hiende tu risa
Fresca free frágil preferida
Frugal aposento de la nueva especie
(«Adonáis», 1, p. 35, vv. 6-12)

$\mathrm{O}$ en el segundo, donde las tmesis parecen obedecer al poema mismo en la exhortación a hender, a ser perforadas y atravesadas, a la vez que el eco del címbalo se derrama en los versos siguientes, e intuimos calambures no explícitos:

\section{Succionas címbalo in resurrection \\ Sino amara mar slowly ara- \\ Ñaba sed hidratada melancolía sub \\ Pop ululaba el ulular popular \\ Del viento veloz perforada \\ Privación de un fecundo mástil \\ Huelo el mar nunca cruel \\ Hiende leda húmeda levedad \\ («Adonáis», 2, p. 36, vv. 1-8)}

La búsqueda deviene transitoriamente infructuosa («qué inencontrado // ritmo escarba esta poesía», p. 32, vv. 11-12), para que al final, en «Egus», el poeta sea hallado por la poesía, iluminado ya, o tal vez encontrado poesía, una vez acaecida la transubstanciación: «Poesía me encuentra tu luz ojo quebrado anís de la melancolía síndrome antesala barrunto oh la música que anudó el pistilo de la innombrada flor aún poseída después de la revelación» (p. 45). Pero el sujeto lírico no pierde en ningún momento su vocación rítmica y, acompañado de Euterpe y Polimnia, canta así:

\section{Mi ser expreso digo es música \\ Ritmical session perdura perdona \\ Poesía yo sé tú sabes lo sabe el pueblo \\ («Eucaristía», 6, p. 26, vv. 10-12)}

La obsesión rítmica le viene a Santiváñez de antaño, no sólo en la vertiente poética, sino también en la meramente musical, aficionado como fue en los 80 limeños a los conciertos de «rock subterráneo» o «pop achorado» ${ }^{22}$. En Symbol, su cuaderno músico, escrito,

\footnotetext{
${ }^{22}$ Véase el trabajo de Ángeles, en concreto las nn. 3 y 11, así como Mazzotti 2002b: 136. Para Ángeles, «si la música es la armonización de sonidos para expresar mensajes, la música de Santiváñez no es, por cierto, aquella apacible, amena ni clásicamente ordenada. Es otra música. Es la violencia sonora de la calle; la estridencia de la orbe actual y de sus personajes más agresivos. Desde allí, Santiváñez nutre temática y musicalmente su lenguaje poético. De ahí que es muy probable que quien esté ajeno a ese "mundanal ruido" (del cual es una expresión contemporánea el rock), o en contra de él, perciba la poesía de Santiváñez como instrumento de sonoridad
} 
siguiendo el consejo de Pound, in the sequence of the musical phrase (Urdanivia: 20), se acrecienta esta pasión que ahora se dilata hasta alcanzar al contenido mismo de la poesía, e incrementando incluso el mimo en la cadencia versal. Así, hay momentos en que el oído se topa con sorprendente polirritmia endecasilábica -en un poemario a veces versolibrista y de carácter marcadamente anisosilábico-, mediante la combinación de pentámetros yámbicos, endecasílabos comunes, sáficos, de gaita gallega, a la francesa y alguno inaudito, con acentuación en tercera, séptima y décima:

\title{
Pétalo sé mi canción exquisita \\ Squizofrénica forado escape divino \\ Hacer poesía lingua franca vulva \\ Volada pasionaria honoris causa \\ En este triste sino de tu signo \\ Sonido flor pesca de un mar celeste \\ Como el cielo que en Colán frikeó \\ («Eucaristía», 2, p. 22, vv. 5-11)
}

Diversos son los tipos de música que repiquetean en el libro, desde la de címbalos y campanas («Así me pusiste tu corazón en cuatro campanas», p. 41, v. 4) al murmullo del río («Ribera river dale fluido bello \& músico // Dial de la melancolía», p. 23, vv. 10-11), o del mar («Ahora que sólo el sonido del mar // Resuena en Magdalena», p. 28, vv. 6-7), pasando por los temblores de la cumbre andina, que retumban en el segundo de los poemas de «Lied»: «Un canto de acanto en el llanto agazapado de Canta» (p. 42, v. 14). Incluso la música contemporánea tiene cabida (rock, techno, underground) y casta para identificarse con una poesía de nuevo cuño: «En esta luz invernal // Escucho la música urbana de mi soledad en Lima: // Es una poesía escrita en el níspero del arrobado sentimiento» (p. 42, vv 1-3). Pero siempre, el misterio, la magia de la música y la poesía como revelación («oh la música que anudó el pistilo de la innombrada flor aún poseída después de la revelación», p. 45) o como resultado del deambular por derroteros ignotos:

\author{
Veo los recónditos recodos en que \\ Cobijó nuestra canción / desenchufado \\ Afán que no volviste a sonreír \\ No sabría escribir tu poesía \\ Sacra mi música misteriosa \& \\ Dulcificada por el confíteor» \\ («Gema», p. 43 , v. 10-12)
}

\begin{abstract}
cacofónica, criatura de un poeta con mal oído que (des)articula versos. Es que esta poesía, en verdad, no se entiende ni se siente adentro si se le saca de este ruido-urbano, de esa ex-profesa desarticulación de la sintaxis amena y conversacional. La música de Santiváñez es la música de la violencia urbana, y nada de eso puede ser, pues, una melodía amena para agarrar sueño o para elevar el alma a estados de paz». Sin embargo, a continuación, el crítico mismo matiza su tajante afirmación: «Cabría ver este aserto, sin embargo, con más cuidado; porque es posible que en este bombardeo melódico se revelen estaciones de sosiego, en diálogo con lo anterior. Así se expresaría, además, el modo real de cómo es la vida: unidad de contrarios, dialéctica» (Ángeles: n. 11).
\end{abstract}


Tal vez la clave de la obra se resuelva precisamente en la fruición por la música y el ritmo, por el sonido de este canto de acanto ofrendado, si no por púberes canéforas, sí por el coro de vírgenes que asiste esta ceremonia poético-eucarística ${ }^{23}$.

\section{El CANTO de Clí́o}

El poeta Róger Santiváñez fue mostrándose reticente, a partir de los primeros años de la década de los 80 , con la posibilidad de que la poesía cambiase el mundo, sin que por eso el hombre haya dejado de estar comprometido con su entorno. Los problemas políticos y sociales de su época han seguido apareciendo en su obra, pero como pretexto para explorar nuevas opciones lingüísticas (pensamos en ese lenguaje lumpenizado de Symbol), como trasfondo o en relación con otros problemas íntimos concernientes al sujeto lírico. Los veinticinco años que separan su primera obra y Eucaristía testimonian el viraje:

Cuando escribí mi primer cuaderno Antes de la muerte (1979) estaba fuertemente preocupado (la época lo exigía, como dice Pound) en enhebrar mi poesía con el sentir de las masas explotadas; deseaba que mis poemas expresaran los sentimientos y aspiraciones del pueblo [...]. Igualmente quería captar toda esa gesta limeña en la que yo había participado, durante la cual el pueblo -después de la reforma velasquista- arrinconó a la dictadura de Morales Bermúdez [...] y lo obligó a convocar la Asamblea Constituyente. [...] En mi segundo cuaderno, Homenaje para iniciados (1984), ya no tenía ninguna preocupación estrictamente política: ya había pasado por la anárquica vida del Movimiento Kloaka; estaba decepcionado de la Izquierda Unida que -salvo honrosas excepciones- no hizo nada por el pueblo al que decía representar en el Congreso [...]. Así las cosas, en este libro me dediqué a cantar el amor erótico y a la separación de los amantes y a una defensa cerrada de un individualismo anarquista frente a cualquier orden establecido. Al mismo tiempo empecé a interesarme por lo que denominamos fraseo en la poesía, o sea el ritmo interno de los versos y su capacidad órfica, ondulante, sensual. Aquí es cuando arranca mi preocupación por el lenguaje en sí mismo, sin importarme mucho -a nivel consciente- de lo que quería significar (Ildefonso).

De acuerdo con esa evolución, el contexto político-social en cuanto tal ocupa un lugar ínfimo en Eucaristía. Las escasos ejemplos que vetean el poemario suelen venir acompañados de un conflicto personal, y, sobre todo, de una intensa exploración del lenguaje y sus posibilidades, en la mejor tradición vallejiana. Y la mayoría de las veces, esas muestras vienen insertas en poemas cuya prioridad no es, ni mucho menos, la testimonial, como en el segundo de los sajones: «Ya no hay pasto // ya no hay guerra ya no sumo ni // resto los cadáveres. Hoy me vuelvo // a sonreír en los espejos de mi madre» (p. 13, vv. 3-6).

El único texto dedicado íntegramente a la cuestión social lo hace desde una perspectiva muy distinta a la de los primeros poemas de Santiváñez. Se trata del undécimo de «Eucaristía», en el que incluso las alusiones, frecuentes en su obra, a otros poetas (Javier

\footnotetext{
${ }^{23}$ G. Stagnaro señala certeramente la capacidad de la obra para influir en el lector por vías distintas a las racionales, como la emotiva, al igual que sucede con la música: «no se condensa en una sola simbolización ni posee un contenido de asimilación inmediata, sino que se abre a las diversificaciones del sentido reconstruidas por la lectura. Descompuesto el lenguaje en sus unidades fonéticas, desprovisto de toda pretensión lógica por la comunicación y convertido en un trasvase en el que entran y salen idiomas y culturas, el poema se vuelve apto para el deslizamiento de la afectividad», «Ceremonias seculares», El Peruano, 81 (Lima, 21 de marzo de 2005), p. 11.
} 
Heraud, poeta guerrillero, muerto a los 21 años, y Rodolfo Hinostroza), tienen implicaciones socio-políticas, y lo tiñen de la vertiente comprometida de aquellos:

Sólo para tu carita de estambre que se

Revienta en millares de hojas esparcidas

Extraños sueños siniestros

Me hicieron doler pero reconocer que

El dolor político no es otro tema de

Mi canción nunca me metí en la trinchera

Me fui hui huyendo como dijo Heraud

Aunque él sí murió por nosotros

Soy hinostroziano no creo

En las guerras no creo en nadie soy

Un lumpen maldita la hora en que hablé

Con un lumpen no soy un lumpen soy

(«Eucaristía», 11, p. 31)

La escisión, un tanto esquizoide, del sujeto poético lo lleva a dudar de su condición de individuo, acuciado por un sentimiento de culpa, que rápidamente se torna justificación o excusa, y después, imprecación y duda. La ausencia de signos de puntuación, así como el encabalgamiento entre los versos noveno y décimo vuelve ambiguos (o por mejor decir, ambivalentes, plurivalentes) los versos finales ${ }^{24}$. La alusión a Heraud reviste al poeta de un cierto halo mesiánico, con el empleo de la expresión morir por nosotros: a la función órfica del poeta se le suma ahora esta otra que empuja al sujeto poético a considerar que no está a la altura de las circunstancias, a proclamar una impostada misantropía. Pero es necesario volver al inicio del poema y a esa carita de estambre a que se dirige para constatar que es falaz el no creo en nadie. La indeterminación sintáctica que caracteriza al poemario nos impide precisar si la oración inicial se trunca en singular aposiopesis o hay que imaginar un elidido verbo entre los versos segundo y tercero; de cualquier modo, es esa persona la que motiva la reflexión y la induce, bien por el amor hacia ella (el diminutivo nos revela el afecto del sujeto hacia la misma) y el consiguiente deseo por parte del sujeto lírico de ser un poco mejor, bien por una asociación de imágenes que vendría provocada por su contemplación. Esos millares de hojas esparcidas podrían aludir tanto a los de una carita sinecdóquicamente transmutada en flor, como a una imagen mucho más comprometida desde el punto de vista político, la de los panfletos y octavillas volantes en un escenario reivindicativo como, por ejemplo, una manifestación. A partir de ahí, serán los extraños sueños siniestros (y el sentimiento de culpabilidad por no haber «entrado en acción» que parece estar ligado a ellos) los que justifican el contenido del poema. Por lo tanto, no se

\footnotetext{
${ }^{24}$ La confusión transitoria que provoca ese encabalgamiento («Soy hinostroziano no creo // En las guerras») ha sido también subrayada por Paolo de Lima, que analiza este poema por considerarlo relevante en la evolución poética de Santiváñez en lo que respecta a su posición ante la violencia estructural del sistema. Para él, estos recursos expresivos encarnan o materializan la propia disgregación del sujeto: «el sujeto poético se ha visto como un lumpen para inmediatamente alejarse de esta identificación y afirmarse en un soy que sin embargo no basta» (De Lima: 288-289).
} 
trata de un poema social con una pretensión por cambiar el mundo, sino que plantea el conflicto íntimo de un individuo ante la posibilidad del cambio y su propia implicación.

$* * * * * * * * *$

Mas nunca hizo verano una golondrina sola. La realidad externa político-social no constituye una de las preocupaciones cruciales del poeta en Eucaristía, aunque esté de algún modo presente. Con lo que se queda el lector que lee y relee el poemario es con la fuerza y exuberancia de un lenguaje pulido hasta la reverberación, con el goce que provoca la eufonía de unos versos sonoros y armónicos, con el desenfrenado erotismo sacro-profano y las insólitas imágenes que de él derivan ${ }^{25}$; con la impresión, en definitiva, de que el poeta oficiante nos despidiera con un renovado Ite, missa est.

\section{REFERENCIAS BIBLIOGRÁFICAS}

ADÁN, Martín, Obras en prosa, Lima, Ediciones Edubanco, 1982.

ÁNGeles L., César, «Aproximación a la poesía peruana de los 80. Punto de partida: la poesía de Róger Santiváñez», Ciberayllu (12 agosto 2001). Internet. 31/03/05 $<$ http://www.andes.missouri.edu/andes/Especiales/CALRoger/CAL_Roger1.htm $1>$

CAlabrese, Omar, A idade neobarroca, São Paulo, Martins Fontes, 1987.

Castillo Durante, Daniel y Borka SATtler (eds.), Perú en su cultura, Ottawa-Lima, Université d'Ottawa-PromPerú, 2002.

CELORIO, Gonzalo, "Aproximación a la literatura neobarroca», Letras de Chile. Internet. 19/04/05.

$<$ http://www.letrasdechile.cl/modules.php?name=News\&file=article\&sid=582>

CHIAMPI, Irlemar, Barroco y modernidad, México, Fondo de Cultura Económica, 2000.

DE LiMA, Paolo, «Violencia y “otredad” en el Perú de los años 80: de la globalización a la "Kloaka"», Revista Crítica Literaria Latinoamericana XXIX, 58 (LimaHanover, 2003), pp. 275-301.

ECHAVARREN, Roberto, «Prólogo», en AA. VV., Medusario. Muestra de poesía latinoamericana, México, Fondo de Cultura Económica, 1996, pp. 11-17.

FREYRE, Maynor, Altas voces de la literatura peruana y latinoamericana. Segunda mitad del siglo XX. Entrevistas - comentarios - reportajes, Lima, Editorial San Marcos, 2000 .

Góngora y Argote, Luis de, Soledades, ed. John Beverley, Madrid, Cátedra, 2003.

GranAdos, Pedro, «De lo neobarroco en el Perú», www.letras.s5.com. Internet. 19/04/05. $<$ http://www.letras.s5.com/pg150305.htm>

\footnotetext{
${ }^{25}$ Como se sabe, el modernismo hispanoamericano fue proclive al contubernio sacro-erótico. Un ejemplo paradigmático es el del poema «Ite, missa est», citado al inicio de este trabajo, en el que Darío recrea el acto amoroso, metafóricamente presentado como rito eclesiástico; en semejante dirección, aunque tal vez con cierta merma de la calidad estética, estarían poemas como «Gratia Plena», «De blanco» o «Liturgia erótica», de Amado Nervo, Gutiérrez Nájera y Julián Herrera y Reissig, respectivamente.
} 
ILDEFONSO, Miguel, «El fuego de la poesía. Entrevista al poeta Róger Santiváñez», Ciberayllu (20 de septiembre de 2004). Internet. 31/03/05. $<\mathrm{http} / / / \mathrm{www}$.andes.missouri.edu/andes/Cronicas/MI_Rsantivanez.html>

LÓPEZ SORIA, José Ignacio, «Diálogo con Eucaristía de Róger Santiváñez», Brújula Internacional. Boletín del Instituto de Escritores Latinoamericanos, I, 4 (2004). Internet. 19/04/05. <http://www.geocities.com/hibrido_literario/brujula.html>

MAzzotTi, José Antonio, «El proceso de la poesía peruana del 80 a cuatro voces», en Daniel Castillo Durante y Borka Sattler (eds.), Perú en su cultura, Ottawa-Lima, Université d'Ottawa-PromPerú, 2002a, pp. 111-158.

Mazzotti, José Antonio, Poéticas del flujo. Migración y violencia verbales en el Perú de los 80, Lima, Fondo Editorial del Congreso del Perú, 2002b.

Medo Ferrero, Mauricio, «Repensando la poesía peruana: una Babel en el continente latinoamericano», www.letras.s5.com. Internet. 13/04/05. $<$ http://www.letras.s5.com/lp140105.htm>

Milán, Eduardo, «Neobarrosos», Zunái. Revista de Poesía \& Debates. Internet, 19/04/05. $<\mathrm{http} / / / w w w . r e v i s t a z u n a i . c o m . b r / e n s a i o s / e d u a r d o \_m i l a n \_n e o b a r r o s o s . h t m>$

Molho, Mauricio, Semántica y poética (Góngora, Quevedo), Barcelona, Crítica, 1977.

PAZ, Octavio [1974], Los hijos del limo, Barcelona, Seix Barral, 1998.

Perlongher, Néstor, «Neobarroco y neobarroso», en AA.VV., Medusario. Muestra de poesía latinoamericana, México, Fondo de Cultura Económica, 1996, pp. 19-30.

Romero, Raúl, «Barroco y Neobarroco. Naturaleza, apoteosis, dificultad, oscuridad», Babab, 22 (noviembre 2003). Internet. 13/04/05. $<$ http://www.babab.com/no22/neobarroco.php>

SANTIVÁÑEZ, Róger, Antes de la muerte, Lima, Hipocampo Editores, 1979.

SANTIVÁÑEZ, Róger, Homenaje para iniciados, Lima, Reyes en el Caos, 1984.

SANTIVÁÑEZ, Róger, El chico que se declaraba con la mirada, Lima, Asaltoalcielo Editores, 1988.

SANTIVÁÑEZ, Róger, Symbol, Princeton, Asaltoalcielo Editores, 1991.

SANTiváÑEZ, Róger, Cor Cordium, Filadelfia, Asaltoalcielo Editores, 1995.

SANTIVÁÑEZ, Róger, Santísima Trinidad, Lima, Hipocampo Editores, 1998.

SANTIVÁÑEZ, Róger, Historia francorum, Lima, Asaltoalcielo Editores, 2000.

SANTIVÁÑEZ, Róger, El corazón zanahoria, Piura, Sietevientos Editores, 2002.

SANTIVÁÑEZ, Róger [2002], Santa María, 2a ed., Lima, Hipocampo Editores-Asaltoalcielo Editores, 2003.

SANTIVÁÑEZ, Róger, Eucaristía, Buenos Aires, Tsé-Tsé, 2004.

SARDUY, Severo, «El barroco y el neobarroco», en César Fernández Moreno (ed.), América Latina en su literatura, México, Siglo XXI, 1972, pp. 167-184.

SARDUY, Severo, Ensayos generales sobre el barroco, México-Buenos Aires, Fondo de Cultura Económica, 1987. 
Siebenmann, Gustav, Poesía y poéticas del siglo XX en la América hispana y el Brasil, Madrid, Gredos, 1997.

Stagnaro, Giancarlo, «Ceremonias seculares», El Peruano, 81 (Lima, 21 de marzo de 2005), p. 11.

URDANIVIA, Eduardo, «Symbol. El cuaderno músico de Róger Santiváñez», Sietevientos, 5 (Piura, 1993), pp. 17-38.

Zevallos Aguilar, Juan, Movimiento Kloaka (1982-1984): Cultura juvenil urbana de la postmodernidad periférica, Lima, Editorial Ojo de Agua, 2002.

ZURITA, Raúl, «La letra en que nació la pena: muestra de poesía peruana 1970-2004», www.letras.s5.com. Internet.

$13 / 04 / 05$.

$<$ http://www.letras.s5.com/lp150105.htm> 
